\title{
Article
}

\section{Development of the Mobile Technology Vulnerability Scale among Youth and Young Adults Living with HIV}

\author{
Nadra E. Lisha ${ }^{1}{ }^{\circ}$, Torsten B. Neilands ${ }^{2}$, Xavier A. Erguera ${ }^{2}$ and Parya Saberi ${ }^{2, *}$ \\ 1 Center for Tobacco Control Research and Education, University of California, San Francisco, CA 94134, USA; \\ nadra.lisha@ucsf.edu \\ 2 Division of Prevention Science, University of California, San Francisco, CA 94158, USA; \\ Torsten.neilands@ucsf.edu (T.B.N.); Xavier.erguera@ucsf.edu (X.A.E.) \\ * Correspondence: Parya.Saberi@ucsf.edu
}

Citation: Lisha, N.E.; Neilands, T.B.; Erguera, X.A.; Saberi, P. Development of the Mobile Technology

Vulnerability Scale among Youth and Young Adults Living with HIV. Int. J. Environ. Res. Public Health 2021, 18, 4170. https://doi.org/10.3390/ ijerph18084170

Academic Editor: Paul B. Tchounwou

Received: 14 March 2021

Accepted: 13 April 2021

Published: 15 April 2021

Publisher's Note: MDPI stays neutral with regard to jurisdictional claims in published maps and institutional affiliations.

Copyright: (c) 2021 by the authors. Licensee MDPI, Basel, Switzerland. This article is an open access article distributed under the terms and conditions of the Creative Commons Attribution (CC BY) license (https:// creativecommons.org/licenses/by/ $4.0 /)$.

\begin{abstract}
Introduction: Youth and young adults living with HIV (YLWH) in the US have the lowest viral suppression percentage. Lack of sufficient technology access may be correlated with HIV health outcomes in this population. Methods: We developed a Mobile Technology Vulnerability Scale (MTVS; 18 items) among 18-29-year-olds. Exploratory factor analysis (EFA) was performed on baseline data $(\mathrm{N}=79)$, followed by a confirmatory factor analysis (CFA) of 6-month follow-up data $(\mathrm{N}=69)$. Cronbach's alpha for internal consistency and test-retest reliability were examined. We also correlated the scale with self-report antiretroviral therapy (ART) adherence. Results: EFA yielded a single-factor solution at baseline after dropping one item. CFA at follow-up corroborated the single-factor. Cronbach's alpha was high and MTVS was correlated with ART adherence at both time points. MTVS at baseline and 6 months were correlated. Conclusion: The 17-item MTVS scale was found to be valid and reliable and related to ART adherence.
\end{abstract}

Keywords: youth living with HIV; technology; mobile telephone; adherence; antiretroviral therapy; scale development

\section{Introduction}

Youth and young adults living with HIV (YLWH) in the US have the lowest percentage of viral suppression (as low as 12-58\%) [1] compared to older age groups and experience significant health disparities with regard to HIV treatment initiation and clinical outcomes [2-6]. Compared to older adults, YLWH have lower antiretroviral therapy (ART) initiation rates, suboptimal ART adherence and care retention, and higher virologic failure rates [6]. Unsuppressed HIV viral load can result in morbidity, drug resistance, and secondary transmission [7]. Prior studies have shown a significant correlation between the use of technology and virologic suppression and ART adherence among people living with HIV [8,9]. Due to the ubiquity of ownership of technologies (such as smartphones) among youth [10] and the need to address health disparities among YLWH $[1-4,6,11]$, technology-based methods to facilitate healthcare services and address health disparities are a logical option.

The Mobile Technology Vulnerability Scale (MTVS) was developed based on food insecurity measures. We use a theory applicable to both constructs, the Conservation of Resources Theory [12], which emphasizes that stress can happen when resources are either lost or at risk of being lost. In fact, anticipatory loss can be as bad as actual loss [12]. Accordingly, we believe that as food insecurity is associated with ART non-adherence [13], so is technology vulnerability.

Here, we report steps in the development and validation of a survey instrument designed to examine the level of "mobile technology vulnerability" among YLWH. We believe that a mobile technology vulnerability scale (i.e., a scale to examine the lack of 
sufficient access to mobile technology to meet personal needs) may be correlated with HIV health outcomes.

\section{Materials and Methods}

Participants and Study Design: We developed the Mobile Technology Vulnerability Scale (MTVS) among 18-29-year-olds living with HIV recruited for a longitudinal pilot trial, evaluating the feasibility and acceptability of a mobile health application called WYZ [14]. MTVS is analogous to the food insecurity scale [15] and examines how secure or stable an individual feels regarding their personal access to mobile technology.

Development: The original mobile technology scale was initially developed by the study Principal Investigator. In an iterative fashion, the scale was reviewed and revised by three psychometrics experts from the UCSF Center for AIDS Prevention Studies (CAPS) Methods Core and one behavioral researcher from the CAPS Developmental Core with expertise in ART adherence and HIV health outcomes. Finally, cognitive interviewing was undertaken with the CAPS Youth Advisory Panel (YAP), whose members are 18-29-year-old YLWH, to further refine the scale by ensuring the cultural appropriateness of the language, enhancing understandability, capturing important issues regarding access and permanency of mobile technology, and overall editing of the scale. Items were revised based on the YAP's feedback, resulting in an initial 18-item instrument that was deployed in our pilot sample of YLWH.

Measures: At baseline, participants of the pilot study were asked their demographics, including age, sex at birth, sexual orientation, race/ethnicity, financial security (I have enough money to live comfortably, I can barely get by on the money I have, I cannot get by on the money I have), and work status.

The Mobile Technology Vulnerability Scale (MTVS) was developed as an 18-item scale designed to measure how secure an individual feels about their access to mobile technology, namely through their mobile phone (Table 1). Participants responded to MTVS questions at baseline and 6 months.

Table 1. Items in the Mobile Technology Vulnerability Scale (MTVS), frequencies, and exploratory factor analysis (EFA) and confirmatory factor analysis (CFA) results.

\begin{tabular}{|c|c|c|c|c|}
\hline & n (\%) & $\begin{array}{l}\text { EFA Rotated Factor } \\
\text { Loadings (All Items) } \\
\text { at Baseline }\end{array}$ & $\begin{array}{l}\text { EFA Rotated Factor } \\
\text { Loadings (without } \\
\text { Item 3) at Baseline }\end{array}$ & $\begin{array}{l}\text { CFA Standardized } \\
\text { Factor Loadings at } \\
\quad 6 \text { Months }\end{array}$ \\
\hline $\begin{array}{l}\text { 1. In the last } 6 \text { months, I was the only } \\
\text { person who used this phone (not } \\
\text { including lending to someone to make a } \\
\text { brief phone call or to look something up } \\
\text { on the internet). }\end{array}$ & $70(91 \%)$ & 0.41 & 0.41 & 0.46 \\
\hline $\begin{array}{l}\text { 2. At any time in the last } 6 \text { months, I } \\
\text { received formal assistance to pay for my } \\
\text { cellphone service (such as Lifeline } \\
\text { Assistance Program/Obama Phone). }\end{array}$ & $9(12 \%)$ & 0.57 & 0.57 & 0.74 \\
\hline $\begin{array}{l}\text { 3. At any time in the last } 6 \text { months, my } \\
\text { family or friends helped me to pay for } \\
\text { my cell phone service. }\end{array}$ & $32(42 \%)$ & 0.26 & - & - \\
\hline $\begin{array}{l}\text { 4. At any time in the last } 6 \text { months, I had } \\
\text { more than one cell phone number. }\end{array}$ & $10(13 \%)$ & 0.53 & 0.53 & 0.81 \\
\hline $\begin{array}{l}\text { 5. At any time in the last } 6 \text { months, my } \\
\text { cell phone was stolen at least once. }\end{array}$ & $10(13 \%)$ & 0.61 & 0.60 & 0.70 \\
\hline $\begin{array}{l}\text { 6. At any time in the last } 6 \text { months, I lost } \\
\text { my cell phone at least once. }\end{array}$ & $12(15 \%)$ & 0.61 & 0.61 & 0.68 \\
\hline $\begin{array}{l}\text { 7. At any time in the last } 6 \text { months, my } \\
\text { cell phone service was disconnected (cut } \\
\text { off) at least once because I didn't pay } \\
\text { the bill. }\end{array}$ & $17(22 \%)$ & 0.78 & 0.78 & 0.85 \\
\hline
\end{tabular}


Table 1. Cont.

\begin{tabular}{|c|c|c|c|c|}
\hline & n (\%) & $\begin{array}{l}\text { EFA Rotated Factor } \\
\text { Loadings (All Items) } \\
\text { at Baseline }\end{array}$ & $\begin{array}{l}\text { EFA Rotated Factor } \\
\text { Loadings (without } \\
\text { Item 3) at Baseline }\end{array}$ & $\begin{array}{l}\text { CFA Standardized } \\
\text { Factor Loadings at } \\
6 \text { Months }\end{array}$ \\
\hline $\begin{array}{l}\text { 8. At any time in the last } 6 \text { months, I did } \\
\text { not pay other bills (example: utilities, } \\
\text { rent, etc.) so I could pay my cell } \\
\text { phone bill. }\end{array}$ & $10(13 \%)$ & 0.89 & 0.89 & 0.92 \\
\hline $\begin{array}{l}\text { 9. At any time in the last } 6 \text { months, I did } \\
\text { not buy necessary items (example: food, } \\
\text { clothes, medication, etc.) so I could pay } \\
\text { my cell phone bill. }\end{array}$ & $14(18 \%)$ & 0.83 & 0.84 & 0.90 \\
\hline $\begin{array}{c}\text { 10. At any time in the last } 6 \text { months, I } \\
\text { did not pay my cell phone bill because I } \\
\text { had to pay for other necessities or } \\
\text { other bills. }\end{array}$ & $15(20 \%)$ & 0.73 & 0.73 & 0.91 \\
\hline $\begin{array}{l}\text { 11. At any time in the last } 6 \text { months, I } \\
\text { had to limit using my cell phone's data } \\
\text { plan for any purpose (such as making } \\
\text { calls, sending text messages, or using } \\
\text { the internet) so that I could keep my cell } \\
\text { phone bill low. }\end{array}$ & $13(17 \%)$ & 0.67 & 0.67 & 0.80 \\
\hline $\begin{array}{l}\text { 12. At any time in the last } 6 \text { months, I } \\
\text { used free internet services (such as } \\
\text { Google Voice, WhatsApp, or Facebook } \\
\text { Messenger's phone option) to make } \\
\text { phone calls because I did not have cell } \\
\text { phone service. }\end{array}$ & $24(32 \%)$ & 0.97 & 0.97 & 0.96 \\
\hline $\begin{array}{l}\text { 13. At any time in the last } 6 \text { months, I } \\
\text { checked email, sent text messages, } \\
\text { checked social media, searched the } \\
\text { internet, or made a call on my cell phone } \\
\text { by using free public Wi-Fi because I } \\
\text { could not afford to use my data plan. } \\
\text { 14. At any time in the last } 6 \text { months, I }\end{array}$ & $24(32 \%)$ & 0.88 & 0.88 & 0.95 \\
\hline $\begin{array}{c}\text { had to use a less reliable (example: } \\
\text { Boost, Cricket, etc.) cell phone service } \\
\text { because it was cheaper than other more } \\
\text { reliable services. }\end{array}$ & $13(17 \%)$ & 0.35 & 0.35 & 0.90 \\
\hline $\begin{array}{l}\text { 15. At any time in the last } 6 \text { months, I } \\
\text { did not make an important phone call } \\
\text { because I was frustrated with my } \\
\text { phone's service. }\end{array}$ & $7(9 \%)$ & 0.78 & 0.78 & 0.92 \\
\hline $\begin{array}{l}\text { 16. At any time in the last } 6 \text { months, I } \\
\text { did not search for important } \\
\text { information that I needed because I was } \\
\text { frustrated with my phone's internet } \\
\text { connection. }\end{array}$ & $16(21 \%)$ & 0.80 & 0.79 & 0.90 \\
\hline $\begin{array}{l}\text { 17. Over the last } 6 \text { months, I had } \\
\text { personal problems (such as missed an } \\
\text { appointment, got lost, was unable to } \\
\text { pay a bill, etc.) because my cell phone } \\
\text { battery died. }\end{array}$ & $17(23 \%)$ & 0.82 & 0.82 & 0.93 \\
\hline $\begin{array}{l}\text { 18. Over the last } 6 \text { months, I had } \\
\text { problems (such as missed an } \\
\text { appointment, got lost, was unable to } \\
\text { pay a bill, etc.) because I didn't pay my } \\
\text { cell phone bill and my cellphone service } \\
\text { was cut. }\end{array}$ & 7 (10\%) & 0.88 & 0.88 & 0.90 \\
\hline
\end{tabular}

Notes: Confirmatory factor analysis (CFA) $(\mathrm{N}=69)$; exploratory factor analysis (EFA) $(\mathrm{N}=79)$. Missing value numbers ranged from 2 to 8 people. Item 1 was reverse coded. Item 3 was removed from the final scale. Factor loadings were estimated via a weighted least squares (WLS) approach in Mplus (Mplus WLSMV estimator). CFA global model fit test result: $\chi^{2}(119)=131.298, p=0.21$. 
The self-reported antiretroviral therapy (ART) adherence scale is a composite of three items; "In the last 30 days, on how many days did you miss at least one dose of any of your HIV medications?" (0-30); "In the last 30 days, how good a job did you do at taking your HIV medications in the way you were supposed to?" ( $0=$ very poor, $5=$ excellent $)$; and "In the last 30 days, how often did you take your HIV medications in the way you were supposed to?" $(0=$ rarely to $5=$ always $)$ [16]. Participants responded to questions at baseline and 6 months. For analyses, item responses for the three adherence items were linearly transformed and combined to be calculated on a $0-100$ scale, with zero being the lowest adherence and 100 the highest [16].

\section{Statistical Analysis}

The sample characteristics were described using means, standard deviations (SD), frequencies, and percentages. To assess the dimensionality of MTVS, we used three complementary techniques: exploratory and confirmatory factor analysis (EFA and CFA, respectively) in Mplus 8.2 [17] and Cronbach's alpha. An EFA analysis was carried out on the baseline data with a GEOMIN (oblique) rotation of the factor structure to achieve a simpler structure with greater interpretability. A weighted least square estimation approach appropriate for the binary items (Mplus estimator WLSMV) was used to extract the factor(s). To determine the number of factors to retain, we considered the following criteria: a factor loading cutoff criteria of 0.32 or larger [18], scree plots of Eigenvalues, model fit chi-square statistics, and three commonly used fit statistics from the structural equation modeling (SEM) literature: root mean square error of the approximation (RMSEA), comparative fit index (CFI), and standardized root mean squared residual (SRMR). We considered any two of the following criteria indicating satisfactory fit: RMSEA $\leq 0.06, \mathrm{CFI} \geq 0.95$, $\mathrm{SRMR} \leq 0.08$, or a non-significant chi-square (i.e., $p \geq 0.05$ ) [19].

Importantly, we considered the interpretability of each EFA solution. We examined solutions with between 1 and 9 factors. Internal consistency was examined by computing Cronbach's alpha. We also examined validity using the Pearson correlation of the scale with self-reported ART adherence. We examined the stability of the factor structure using a confirmatory factor analysis (CFA) with data at the 6-month follow-up. Lastly, because our expectation was that technology vulnerability would be a relatively stable construct in our population during this 6-month interval, we explored test-retest reliability via a Pearson correlation of the two total scale scores from baseline and 6 months.

\section{Results}

Demographics: The sample consisted of 79 study participants with a mean age of 27.0 $(\mathrm{SD}=2.9)$, who were predominantly male $(87 \%)$, Latino $(43 \%)$, non-Hispanic Black $(21 \%)$, and non-heterosexual ( $89 \%$ ). The sample mostly worked (36\% full time, $22 \%$ part-time), and $67 \%$ stated that they could "barely get by" or could "not get by" on the money that they had. At baseline and 6 months, ART adherence was $85 \%$ at both time points.

EFA and CFA: For the EFA of baseline data, we determined that the best fitting model is a single-factor solution as this factor was clearly dominant based on strong loadings on all the items except one (Table 1). Item three loaded below our cutoff of 0.32 (loading $=0.25$ ); therefore, we dropped this item and re-ran the EFA with the remaining items. Without item three, the results also indicated a single-factor solution. The Eigenvalues, examined via a scree plot, showed a clear drop off after the first factor. In addition, the one-factor model had a non-significant chi-square $\left(\chi^{2}=133.3, \mathrm{df}=119, p=0.17\right)$, indicating good model fit and all the items loaded above 0.35 , with most being above 0.50 . RMSEA (0.04, $90 \%$ confidence interval $(\mathrm{CI})=0.00,0.07 ; \mathrm{CFI}=0.98$; and $\mathrm{SRMR}=0.19)$ also satisfied the SEM criteria for good fit. Lastly, the CFA using a single factor model with the 6-month data, indicated good fit via RMSEA $(0.04,90 \% \mathrm{CI}=0.00,0.07 ; \mathrm{CFI}=0.99$; $\mathrm{SRMR}=0.16$; and $\chi^{2}=131.3, \mathrm{df}=119, p=0.21$ ).

Cronbach's alpha, validity, and test-retest reliability: Next, we examined the internal consistency reliability of the scale using Cronbach's alpha at baseline and 6 months. MTVS 
exhibited a strong alpha of 0.84 (baseline) and 0.90 (six months). We created a MTVS score by taking the mean of the 17 items and correlated that score with self-reported ART adherence. MTVS was correlated with the self-reported ART adherence (baseline: $\mathrm{r}=-0.31$, $p=0.008$, six months: $\mathrm{r}=-0.55, p<0.0001$ ). In other words, there was a statistically significant correlation between increased technology vulnerability and decreased ART adherence. The Pearson's correlation between MTVS at baseline and 6 months was 0.51 $(p<0.0001)$, supporting our expectation that technology vulnerability was stable in our population across the 6-month measurement period of the study.

\section{Discussion}

To our knowledge, this is the first report of a mobile technology vulnerability scale and its association with ART adherence. YLWH are disproportionately affected by health disparities and often exhibit lower adherence to ART. As part of a pilot trial examining the usefulness of a mobile health application targeting these health disparities, we examined a new scale, MTVS, as a possible correlate of HIV health outcomes.

The results indicate that the data best fit a single-factor solution, both using an EFA at baseline and a CFA at 6 months. The CFA revealed high factor loadings with only a few items having smaller loadings (i.e., items 1 and 14). The internal consistency of the scale was excellent, as evaluated using Cronbach's alpha. The scale appeared valid as it exhibited a negative correlation with self-reported ART adherence in the expected direction, indicating that more technology vulnerability was related to lower ART adherence. The scale also demonstrated good test-retest reliability as baseline MTVS was correlated with 6-month MTVS.

Limitations of study include a convenience sample and relatively small sample size of YLWH living and/or receiving health services in the San Francisco Bay Area, which limits the generalizability of our findings. Additionally, we relied on self-reported ART adherence, which is subject to recall and social desirability biases and may represent an over-estimation of actual ART adherence. However, overestimation of adherence by self-report measures would lower variance in adherence, which would weaken its correlation with MTVS, suggesting that MTVS could be even more strongly correlated with biomarker-based measures of adherence. Future studies should evaluate this possibility using biomarkers of ART adherence.

As YLWH have lower rates of ART initiation and adherence resulting in unsuppressed HIV viral load, it is important to identify which factors are associated with these health outcomes. MTVS appears to be a valid and reliable scale that is associated with ART adherence. Future research should examine further refinements of MTVS questions with moderate loadings, the association of MTVS with other objective HIV health outcomes, the use of MTVS in other populations, and the impact of interventions aimed to increase MTVS on improved ART adherence. Exploring other aspects of construct validity (e.g., convergent/divergent validity) should also be studied in future research.

Among youth and young adults, technology is nearly ubiquitous [10]. In addition, younger age groups have lower ART adherence versus older age groups [6], thus, it is possible that the association between MTVS and ART adherence is more prominent in the younger age groups.

\section{Conclusions}

Factor analyses of MTVS yielded a single factor. The resulting scale is reliable and related to ART adherence. MTVS might be useful in future research to identify subgroups of the population who may experience vulnerability regarding their personal access to technology and subsequent downstream health outcomes, such as low medication adherence. In clinical practice, medical professionals may consider asking patients about their mobile technology vulnerability and referring them to programs that can assist in acquiring the needed technology. 
Author Contributions: P.S. contributed to the conception and design of the study. X.A.E. helped with data collection. N.E.L. analyzed the data. N.E.L. and P.S. wrote the first draft of the manuscript. All authors edited and approved the final manuscript. All authors have read and agreed to the published version of the manuscript.

Funding: The authors' work was supported by the National Institute of Mental Health (NIH) (award number R34MH114604). The content is solely the responsibility of the authors and does not necessarily represent the official views of the NIH.

Institutional Review Board Statement: The study was conducted according to the guidelines of the Declaration of Helsinki and approved by the Institutional Review Board (or Ethics Committee) of the University of California, San Francisco (protocol code 16-20393 and approval on 13 July 2020).

Informed Consent Statement: Informed consent was obtained from all subjects involved in the study.

Data Availability Statement: The dataset generated and analyzed during the current study are available from the corresponding author on reasonable request.

Acknowledgments: We thank the UCSF Center for AIDS Prevention Studies' Youth Advisory Panel, who guided us in developing this survey, and the San Francisco Bay Area youth and young adults who participated in the study.

Conflicts of Interest: The authors declare no conflict of interest.

\section{References}

1. Harris, N.S.; Johnson, A.S.; Huang, Y.-L.A.; Kern, D.; Fulton, P.; Smith, D.K.; Valleroy, L.A.; Hall, H.I. Vital signs: Status of human immunodeficiency virus testing, viral suppression, and HIV preexposure prophylaxis_United States, 2013-2018. Morb. Mortal. Wkly. Rep. 2019, 68, 1117. [CrossRef] [PubMed]

2. Doshi, R.K.; Milberg, J.; Jumento, T.; Matthews, T.; Dempsey, A.; Cheever, L.W. For many served by the Ryan White HIV/AIDS Program, disparities in viral suppression decreased, 2010-2014. Health Aff. 2017, 36, 116-123. [CrossRef]

3. Doshi, R.P.; Aseltine, R.H.; Sabina, A.B.; Graham, G.N. Racial and ethnic disparities in preventable hospitalizations for chronic disease: Prevalence and risk factors. J. Racial Ethn. Health Disparities 2017, 4, 1100-1106. [CrossRef] [PubMed]

4. Castel, A.D.; Kalmin, M.M.; Hart, R.L.; Young, H.A.; Hays, H.; Benator, D.; Kumar, P.; Elion, R.; Parenti, D.; Ruiz, M.E. Disparities in achieving and sustaining viral suppression among a large cohort of HIV-infected persons in care-Washington, DC. AIDS Care 2016, 28, 1355-1364. [CrossRef] [PubMed]

5. Castellsagué, X.; Muñoz, N.; De Stefani, E.; Victora, C.G.; Castelletto, R.; Rolón, P.A.; Quintana, M.J. Independent and joint effects of tobacco smoking and alcohol drinking on the risk of esophageal cancer in men and women. Int. J. Cancer 1999, 82, 657-664. [CrossRef]

6. Zanoni, B.C.; Mayer, K.H. The adolescent and young adult HIV cascade of care in the United States: Exaggerated health disparities. AIDS Patient Care STDs 2014, 28, 128-135. [CrossRef] [PubMed]

7. Crepaz, N.; Tang, T.; Marks, G.; Mugavero, M.J.; Espinoza, L.; Hall, H.I. Durable viral suppression and transmission risk potential among persons with diagnosed HIV infection: United States, 2012-2013. Clin. Infect. Dis. 2016, 63, 976-983. [CrossRef] [PubMed]

8. Saberi, P.; Catz, S.L.; Leyden, W.A.; Stewart, C.; Ralston, J.D.; Horberg, M.A.; Grothaus, L.; Silverberg, M.J. Antiretroviral therapy adherence and use of an electronic shared medical record among people living with HIV. AIDS Behav. 2015, 19, 177-185. [CrossRef] [PubMed]

9. Saberi, P.; Johnson, M.O. Correlation of internet use for health care engagement purposes and HIV clinical outcomes among HIV-positive individuals using online social media. J. Health Commun. 2015, 20, 1026-1032. [CrossRef] [PubMed]

10. Pew Research Center. Mobile Fact Sheet. Internet \& Technology. Available online: https://www.pewresearch.org/internet/factsheet/mobile/ (accessed on 9 April 2021).

11. Colasanti, J.; Kelly, J.; Pennisi, E.; Hu, Y.-J.; Root, C.; Hughes, D.; Del Rio, C.; Armstrong, W.S. Continuous retention and viral suppression provide further insights into the HIV care continuum compared to the cross-sectional HIV care cascade. Clin. Infect. Dis. 2016, 62, 648-654. [CrossRef] [PubMed]

12. Hobfoll, S.E. Conservation of resources: A new attempt at conceptualizing stress. Am. Psychol. 1989, 44, 513. [CrossRef] [PubMed]

13. Young, S.; Wheeler, A.C.; McCoy, S.I.; Weiser, S.D. A review of the role of food insecurity in adherence to care and treatment among adult and pediatric populations living with HIV and AIDS. AIDS Behav. 2014, 18, 505-515. [CrossRef] [PubMed]

14. Erguera, X.A.; Johnson, M.O.; Neilands, T.B.; Ruel, T.; Berrean, B.; Thomas, S.; Saberi, P. WYZ: A pilot study protocol for designing and developing a mobile health application for engagement in HIV care and medication adherence in youth and young adults living with HIV. BMJ Open 2019, 9, e030473. [CrossRef] [PubMed]

15. Reeder, C.; Neilands, T.B.; Palar, K.; Saberi, P. Food Insecurity and Unmet Needs Among Youth and Young Adults Living With HIV in the San Francisco Bay Area. J. Adolesc. Health 2019, 65, 262-266. [CrossRef] [PubMed]

16. Wilson, I.B.; Lee, Y.; Michaud, J.; Fowler, F.J.; Rogers, W.H. Validation of a new three-item self-report measure for medication adherence. AIDS Behav. 2016, 20, 2700-2708. [CrossRef] [PubMed] 
17. Muthén, L.; Muthén, B. MPlus User's Guide, 5th ed.; Muthén \& Muthén: Los Angeles, CA, USA, 2007.

18. Comrey, A.L.; Lee, H.B. A First Course in Factor Analysis; Psychology Press: Hove, UK, 2013.

19. Hu, L.; Bentler, P.M. Cutoff criteria for fit indexes in covariance structure analysis: Conventional criteria versus new alternatives. Struct. Equ. Model. Multidiscip. J. 1999, 6, 1-55. [CrossRef] 